holm; Prof. B. A. Houssay, formerly professor of physiology in the University of Buenos Aires; Prof. $F$. H. Knight, professor of social sciences in the University of Chicago ; Prof. H. R. Kruyt, formerly professor of physical chemistry in the University of Utrecht; Prof. E. O. Lawrence, professor of physics in the University of California; N. A. MacR. MacKenzie, president of the University of British Columbia; Sir Arcot Mudaliar, vice-chancellor of the University of Madras; Prof. J. Ortega y Gasset, formerly professor of philosophy in the University of Madrid ; Lord Reith of Stonehaven; Prof. D. S. Russell, professor of pathology in the University of London; Prof. L. S. Ruzicka, professor of organic chemistry in the Swiss Federal Institute of Technology ; Prof. René Sand, professor of social medicine in the University of Brussels; Prof. G. G. Simpson, professor of vertebrate palæontology in Columbia University ; Prof. Norman Kemp Smith, formerly professor of logic and metaphysics in the University of Edinburgh ; Prof. J. G. Sölch, professor of geography in the University of Vienna; Sir Richard Southwell, formerly rector of the Imperial College of Science and Technology, University of London; Prof. S. Timoshenko, professor of mechanics in Stanford University; Prof. O. Veblen, formerly professor of mathematics in the Institute for Advanced Study at Princeton; Prof. C. E. Weatherburn, professor of mathematics in the University of Western Aus. tralia; and Prof. G. H. Whipple, professor of pathology in the University of Rochester. The speakers on behalf of the new graduates were the Bishop of Strängnäs, Lord Reith, the president of Princeton University and the president of the University of British Columbia. The new and past doctors and their wives were afterwards entertained to luncheon in the Bute Hall by the Chancellor, Court and Senate, when replies to the toast of "The New Graduates" were made by Prof. C. H. Dodd, of Cambridge, and Prof. L. S. Ruzicka, of the Swiss Federal Institute of Technology.

The Wednesday programme was completed by two happy social functions at which Town and Gown mingled, an afternoon reception at the Trades House by the Deacon-Convener of the Trades of Glasgow and the Collector of the Trades House, and a reception in the evening at the City Chambers by the Lord Provost and Magistrates.

At the opening of the Oration Ceremony on June 12 , the Chancellor expressed the regret of all that Their Majesties the King and Queen were unable to grace the gathering with their presence, and the Principal read an address from the University to the King and a gracious message from His Majesty. Lord Macmillan then delivered the Commemoration Oration, an eloquent tribute to the past achievements of the University and expression of the ideals which should guide its future. The conclusion of this ceremony, the last of the academic functions of the celebrations, was most fittingly the maiden speech of the Prime Minister as a doctor of the University of Glasgow. More than two thousand guests attended a reception at the University on the Thursday afternoon. In the evening, while their wives were the guests of Lady Hetherington at an 'at home' in the College Rooms, the delegates and new graduates were entertained to dinner by the Senate in the Grosvenor Restaurant. Robes and formalities were laid aside. The Principal presided and the speakers at the dinner included the Vice-Chancellors of the Universities of Cambridge and London, Dr. H. R.
Kruyt of the Universities of Utrecht and Amsterdam, and Dr. B. Blanshard of Yale University.

On June 22, a precedent was followed that had been created fifty years before (almost to the day) on the occasion of the ninth jubilee, when the University took its guests for a cruise on the Firth of Clyde. As in 1901, it was a day of midsummer sunshine and the Firth a panorama of mellow beauty. The Queen Mary $I I$ sailed in the morning with eight hundred guests from Bridge Wharf in the centre of the city past the shipyards and Dunbarton Rock and cruised in the Kyles of Bute, Loch Striven and Loch Riddon, returning round the Cumbraes to Wemyss Bay, whence the journey to Glasgow in the evening was made by train. On the morning of June 23, some 150 guests who still remained were taken by coach to Loch Lomond.

The following week was reserved for gatherings of Glasgow's own graduates, and more than three thousand members of the General Council and their wives were entertained in the Bute Hall on June 25, 27,28 and 29.

J. B. NEILSON

\section{AMERICAN PHYSICAL SOCIETY}

\section{ANNUAL MEETING}

$\mathrm{T}$ HE 1951 annual meeting of the American Physical Society was held at Columbia University, New York City, during February 1-3. The annual meeting of the American Association of Physics Teachers took place simultaneously at Barnard College. At the joint session of the two bodies on February 2, the retiring presidential address of the Physical Society was delivered by Prof. I. I. Rabi, who took as his subject "Molecular Beam Researches in Nuclear and Electronic Physics"; the Oersted Medal of the Association was presented to Prof. J. W. Hornbeck (who died on February 27) ; and the tenth Richtmyer Memorial Lecture was delivered by Prof. J. C. Slater, who spoke on "The Electron Theory of Metals". The after-dinner speaker at the banquet in the evening was Prof. J. R. Oppenheimer, who spoke principally about meson theory.

At the business meeting of the Physical Society the following officers were elected : President, C. C. Lauritsen; Vice-President, J. H. Van Vleck; Secretary, K. K. Darrow; Treasurer, G. B. Pegram ; Managing Editor, S. A. Goudsmit. The headquarters of the Physical Review have now been removed from the University of Minnesota, which housed them for the past quarter of a century, to the Brookhaven National Laboratory.

Twenty-eight invited papers, in addition to two hundred and ninety-one (a new record) ten-minute papers, were contributed to the meeting of the Physical Society. The invited papers included : a group of papers describing the Brookhaven National Laboratory and the research work carried on there; various papers on nuclear physics, including one by C. C. Lauritsen on the work on nuclear energy-levels at the California Institute of Technology; four papers mainly concerned with mesons; in the division of electron physics, J. A. Hornbeck on a review of positive-ion mobilities in the noble gases; in the division of fluid dynamics, $E$. Teller on magneto-hydrodynamics and G. Birkhoff on some modern problems in classical hydrodynamics; $\mathrm{J}$. Bardeen on supraconductivity and lattice vibrations, and two contributions by English visitors, S. Chap- 
man on some phenomena of the upper atmosphere and M. H. L. Pryce on nuclear hyperfine structure of paramagnetic resonance. A complete list of the papers, together with abstracts, is given in the minutes of the meeting, which are printed in the April 15 issue of the Physical Review $(82,291 ; 1951)$.

It was reported that the membership was 9,740 , and that the income of the Society had exceeded expenditure by a substantial amount, but that there was little hope that the Society would be equally fortunate during 1951. A change in the by-laws was approved which empowered the Council to fix the terms on which members of the Society shall receive either Physics Abstracts or Engineering Abstracts. The subscription prices at which these journals are sold to the Society by the Institution of Electrical Engineers, London, have recently been raised, and the purpose of the amended by-law is to enable the Council to recover the extra cost. A committee was appointed to make recommendations about the future relations of the Society and Science Abstracts.

The minutes include a copy of the letter sent by Dr. D. W. Bronk, president of the National Research Council, on December 11, 1950, to R. L. Clark, the director of the Manpower Office of the National Security Resources Board, in which specific recommendations with regard to the question of scientific man-power in the United States of America, the setting up of a National Scientific Personnel Board and the establishment of a register of professionally qualified scientific workers are outlined. The Council of the Physical Society formally approved of these recommendations.

\section{MOVEMENT OF SWIFTS IN SUMMER}

$\mathrm{T}$

HE year 1950 was a good one for studying the movements of swifts (Apus apus), and during the year the movements of forty thousand birds were recorded : a report on the observations has been made by H. G. Hurrell and recently described in British Birds (44, No. 5 ; May 1951).

Movements were found to take place not only during arrival and departure but also in the middle of the breeding season as well. The date when movement occurs is the main reason for classifying it as immigration, emigration or a movement occurring between the two. There is no certain way of distinguishing movements in the field, although there is a tendency for larger numbers of birds to group together when they are leaving Great Britain.

Swifts appear to penetrate the country from the south and work northwards. Arrivals over many years average a day or two earlier in the south than in the south-east. The east coast as a rule is reached rather late and usually in such small numbers that there is little to indicate any spring passage of swifts from the British Isles to other countries.

It is difficult to say when the arrival period ends because movements which have a migratory appearance may take place at any time while swifts are in Britain. Large movements occur in June and early July. These are thought to be undertaken because unfavourable weather forces the swift to seek regions with more adequate food supplies; the food of the swift is adversely affected by the passage of a cyclone or depression.

In 1947 Koskimies suggested that the birds tried to avoid an advancing depression by flying against the wind round the south-east side of it, and that these weather movements are undertaken by first-year nonbreeding swifts and, to a varying extent, by the breeding birds. If mid-season movements were always bad-weather movements, a comparison of the data with meteorological records should show some kind of broad correlation. At times this could be found; but there are cases when there is no obvious connexion between major movements and low temperatures or low pressures. The 1950 mid-breeding season records took place at a time whon weather conditions were comparatively stable and an anticyclone was maintaining fine warm weather over most of the British Isles. Nor is there clear evidence that the birds. taking part in these woather movements are firstyear non-breeding swifts. As yet the evidence is insufficient to say whether large mid-season movements are composed mainly of British swifts or of swifts which have just arrived from overseas.

It is impossible to say when emigration begins, since it commences during July when mid-season movements may still be taking place. Many breeding and most non-breeding swifts leave during July. During this month in 1950 swifts were frequently on the move, while August showed an almost complete absence of any swifts flying northwards; the main directions were south or south-west. Early in August the British Isles are practically drained of breeding swifts. Yet quite large numbers were recorded throughout the month at favoured spots, especially on the east coast. During the last ten days of August, there was a widespread and, for the time of the year, remarkably strong wave. Such large numbers on these late dates are surprising, and it is suspected that these are largely swifts from other countries in more northerly latitudes visiting Britain on their return passage.

In another article in the same issue of British Birds ("The Use of Mobile Observers in the Study of Patterns of Migration"), Arnold Darlington criticizes much of the work on the migration of swifts which has been done in recent years because observations have been made at fixed vantage points, a method which has inherent in it several possible errors.

These errors are reduced if watchers deploy over an area and attempt to locate the main concentrations of swifts and to follow up any flight-lines radiating from them. The use of mobile squads of observers operating on bicycles has proved particularly useful, skilled riders being able to ride at a speed greater than the ground-speed of a migrant swift. In May 1950 the use of fifty-seven cyclists experienced in this mobile method of observation and operating in nineteen units enabled an intensive study to be made of the distribution of migrating swifts passing through south Cambridgeshire. From their results it would appear that, first, in anticyclonic, stable conditions, with light wind and mild temperatures, the movement of swifts tends to follow individual tracks and, although flight-lanes may be followed to some extent, they are not immediately apparent and may require careful seeking. The swifts tend, however, to be attracted by certain places, and here the flight-lanes may become concentrated and obvious, often persisting in their essential form for days on end. Second, in more unsettled conditions, with strong wind, low temperatures and cloud, the swifts may take to watercourses in great numbers, flying low and tending to 'pile up' in some places.

T. H. HAWKINS 